Chapter in Ursula Renz (ed.), Self-knowledge: a history ("Oxford Philosophical Concepts" series).

Oxford University Press, 2017.

\title{
Self-knowledge in Kierkegaard
}

\section{John Lippitt}

Throughout his authorship, Kierkegaard shows an intense fascination with Socrates and Socratic self-knowledge. This chapter will trace, in roughly chronological order: (1) the young Kierkegaard's autobiographical reflections on self-knowledge, when first coming to understand his task as an author; (2) Socrates as a negative figure in The Concept of Irony where self-knowledge is understood in terms of separation from others and the surrounding society - and the contrast with the Concluding Unscientific Postscript's treatment of Socrates as an exemplary "subjective thinker"; (3) in Either/Or, the connection between selfknowledge and self-transparency, and the link between self-knowledge and "choosing oneself", understood as willing receptivity; (4) in writings such as The Concept of Anxiety and The Sickness Unto Death, the importance of sin and our utter dependence upon God for the question of whether self-knowledge is ever really possible; and (5) in Judge for Yourself! and related journal entries, a more precise specification of what Christian self-knowledge might amount to. I shall show that, in his account of self-knowledge as much as elsewhere, treatments of Kierkegaard as a proto-existentialist risk misleadingly downplaying the deeply and explicitly Christian nature of his thought.

\section{1) Youthful reflections}

Kierkegaard raises the importance of "knowing oneself" very early on. In a letter to a student friend written at the age of 22 , he admits that he has enjoyed the limelight and attention of fellow students when in Copenhagen, something he considered a weakness in himself. He admires the "strength" of those fish able to remain in the depths of the sea out of view, rather 
than feeling the need, like the sunfish, "to display one's silvery light on the surface" (LD 48). ${ }^{1}$ He reports that his summer trip to the small northern village of Gilleleje (from which the letter is written) is enabling him "to focus upon my inner self, it spurs me on to comprehend myself, my own self, to hold it fast in the infinite variety of life, to direct towards myself that concave mirror with which I have attempted until now to comprehend life around me" (LD 49). Socratic inwardness is starting to bite. A month later, still in Gilleleje, Kierkegaard wrote one of his most famous journal entries, which is about selfknowledge in the sense of finding "the idea for which I am willing to live and die" (KJN1/SKS17 AA: 12). This entry is often cited (somewhat misleadingly) as one of the founding texts of existentialism. It indirectly introduces tropes, such as "truth as subjectivity", that will later feature so strongly in some of the best-known (and most commonly misunderstood) aspects of Kierkegaard's authorship. Here the young Kierkegaard downgrades the importance of any theorising in which the subject is not himself passionately engaged. ${ }^{2}$ It is in this sense that we should understand his assertion that: "One must first learn to know oneself before knowing anything else. Only when the person has inwardly understood himself, and then seen the way forward on his path, does his life acquire repose and meaning" (ibid.).

2) Socrates and self-knowledge in The Concept of Irony - and later

Few readers of Kierkegaard could fail to notice his admiration for Socrates, the "wise old man of antiquity", as he tends to call him. In the pseudonym Johannes Climacus' Concluding

\footnotetext{
${ }^{1}$ Letter to P. E. Lind, 6 July 1835.

2 "And what use would it be ... if I were to discover a so-called objective truth, or if I worked my way through the philosophers' systems and were able to call them all to account on request, point out inconsistencies in every single circle?; ... What use would it be to be able to propound the meaning of Christianity, ... if it had no deeper meaning for myself and $m y$ life?" (ibid.)
} 
Unscientific Postscript (1846), Socrates is presented as an exemplar not only of "indirect communication" but also of the valorized figure labeled the "subjective thinker". Socrates' approach to self-knowledge is key here, in that Climacus focuses on how Socrates "was occupied solely with himself" (CUP 147n/SKS7 137n). What he means by this can be seen in Socrates' discussion of whether the soul is immortal: what impresses Climacus is that Socrates "stakes his whole life on this "if"" (CUP 201/SKS7 185); he is continually concerned with making the abstract question of whether the soul is immortal concrete ("the relation of the existing person, in his very existence, to what is said" (CUP 202-3/SKS7 185-6)). But there are important shifts in the views of Socrates presented in different parts of the Kierkegaard corpus, and the concomitant relation to the question of self-knowledge. In his postgraduate dissertation The Concept of Irony (1841), Kierkegaard notes how customary it is to characterise Socrates' position with "the well-known phrase", know thyself. ${ }^{3}$ But his position in that text is that Socrates is a purely negative figure. Kierkegaard complains that the phrase "know thyself" is "often torn completely out of the complex of ideas to which it belongs and for some time now has been vagabonding in literature unchallenged" (CI 177/SKS1 224). Rather than the phrase being about "subjectivity in its fullness, inwardness in its utterly infinite wealth", for Socrates it has a starker meaning: "separate yourself from the other" (ibid.). This connects with Kierkegaard's ostensibly audacious claim that the self did not exist prior to Socrates (ibid.). How so?

First, on the question of Socrates' private daimon, Kierkegaard sides with Plato's view that the daimon only warns Socrates against doing certain things, as opposed to Xenophon's view that the daimon also urged him to positive actions. Ultimately Socrates' negativity inheres in his characteristic irony ("infinite absolute negativity", to borrow Hegel's phrase). Socrates is

\footnotetext{
${ }^{3}$ Kierkegaard returns numerous times to passage 229c-230a in Plato's Phaedrus: see for instance FT 100n, R 162-3 and PF 39, 47.
} 
a figure who justifiably uses his chief weapon - irony - against both the unreflective acceptance of conservative morality and the sophists' trickery. But from the state's perspective, this is as dangerous as his trial judged it to be; Socrates is a negative figure who has turned away from his society's traditional beliefs and values. In his discussion of Hegel's view of Socrates, Kierkegaard associates "knowing oneself" precisely with having taken oneself out of the "substantial ethic" of the surrounding Greek culture (CI 228/SKS1 270). And this is contagious: as a result of Socratic questioning, each individual becomes alienated from others and the wider society, and simply left to find the truth within himself.

So the claim that the self does not exist prior to Socrates refers to a radical dependence of each individual upon himself. But also relevant here is Reidar Thomte's suggestion that Kierkegaard's method in The Concept of Anxiety (1844) - "keyed to the principle unum noris omnes" [If you know one, you know all] - expresses "the same as the Socratic 'know yourself". As Thomte glosses this, "every human being possesses, or is within himself, a complete expression of humanness, whose essential meaning cannot be gained from scientific studies" (CA xv). What is common to all human beings is available to each of us through self-reflection - but not of a purely abstract kind. The view is that neither speculative philosophy nor natural science can disclose to me my essential nature. Rather, "Selfknowledge is attained by man in existing; that is, self-knowledge is coordinate with the actualizing of one's potentiality to become oneself' (ibid.) Perhaps, amongst other things, this betokens a shift from the early view of Socrates as pure negativity to what has seemed to several commentators as a significantly different Socrates in the Climacus writings (Fragments and Postscript), in which, as Paul Muench puts it, Socrates' ethically engaged 
"philosophical activity is not a mere precursor to something else but [is] itself the human ideal (the best ethical and religious life available outside of Christianity)". ${ }^{4}$

\section{3) Self-knowledge and self-transparency}

Another theme worth noting in The Concept of Irony is Kierkegaard's view of what "living poetically" truly means. Against the romantics, Kierkegaard stresses being "absolutely transparent to [one]self". He claims: "living poetically is not the same as being in the dark about oneself $\ldots$ but it means becoming clear and transparent to oneself, not in finite and egotistical self-satisfaction but in one's absolute and eternal validity" (CI 298/SKS1 332, my emphasis).

Both self-transparency and grasping oneself in one's "eternal validity" are significant themes in his first major post-dissertation work, Either/Or (1843). In his second letter to the aesthete "A" in the second part of that work, the ethicist Judge William asserts that "to become conscious in one's eternal validity is a moment that is more significant than everything else in the world" (EO II 206/SKS3 198). This is what it means to recognise what one is and is meant to be ("before God"); precisely that which "A" is trying to hide from himself. Grasping oneself in one's "eternal validity" is presented as being the way in which one can unify the temporal and eternal aspects of the self; and possibility and necessity (EO II 231-2/SKS3 221-2). ${ }^{5}$ Choosing oneself "in freedom" (possibility and particularity) and yet "in repentance"

\footnotetext{
${ }^{4}$ Paul Muench, "Kierkegaard's Socratic point of view", in Kierkegaard Research: Sources, Reception and Resources, Vol. 2, Kierkegaard and the Greek World, Tome I: Socrates and Plato, eds. Jon Stewart and Katalin Nun (London: Ashgate, 2010): 18-19; cf. John Lippitt, Humour and Irony in Kierkegaard's Thought (Basingstoke: Palgrave, 2000).

${ }^{5}$ Compare here the 1840 journal entry in which Kierkegaard glosses "eternal validity" in terms of both my "divine necessity" and my "accidental finitude" (being born as a specific individual in a particular land at a particular time) (JP2: 1587/Pap. III A 1).
} 
requires one continually to realise this freedom in action; "He who has chosen himself on this basis is eo ipso one who acts" (EO II 232/SKS3 222).

In that same letter, the Judge presents self-knowledge as key to the difference between the "aesthetic" and "ethical" modes of life. The ethical individual's being transparent to himself “encompasses everything”:

The person who lives ethically has seen himself, knows himself, penetrates his whole concretion with his consciousness, does not allow vague thoughts to rustle around inside him or let tempting possibilities distract him with their juggling; he is not like a "magic" picture that shifts from one thing to another, all depending upon how one shifts and turns it. He knows himself. The phrase know yourself is a stock phrase, and in it has been perceived the goal of all a person's striving. And this is entirely proper, but yet it is just as certain that it cannot be the goal if it is not also the beginning. The ethical individual knows himself, but this knowing is not simply contemplation, for then the individual comes to be defined according to his necessity. It is a collecting of oneself, which itself is an action, and this is why I have with aforethought used the expression "to choose oneself” instead of “to know oneself". (EO II 258/SKS3 246)

So what matters most about self-knowledge is that it is a crucial precursor to the development of an "authentic" individual. But it is important to note here that by "choosing oneself" Judge William has in mind something very different from radical choice à la Sartre. Elsewhere he qualifies this by replacing talk of "choosing" oneself with "receiving" oneself (EO II 177/SKS3 172) - that is, willing receptivity; recognising what are, and are not, serious possibilities for you. Here, the active striving will is complemented - indeed, to some extent replaced - by a more passive recognition of value that breaks through, requiring our 
acknowledgment. ${ }^{6}$ In working out the implications of this, there is an important interplay between possibility and necessity, and between first- and third-person perspectives which we shall need to explore in more detail.

\section{4) Self-knowledge: first- or third-personal? The problem of sin and dependence upon God}

Is "Socratic" self-knowledge essentially first-personal, or does third-personal knowledge of human properties also count? I shall argue that for Kierkegaard, we need both: despite his association with slogans such as "truth is subjectivity", it is not just the former. Later, I shall suggest how he tries to hold both together, in such a way that there is also a crucial secondperson aspect in how we are to relate to God.

Kierkegaard tackles this question obliquely in The Concept of Anxiety. His pseudonym Vigilius Haufniensis criticises the "German" view of self-knowledge as being about "pure self-consciousness, the airiness of idealism" (CA 79/SKS4 382). The target here is typically taken to be Danish Hegelians who had imported Hegel's idea that self-knowledge is not about my particular character, capacities, flaws, and so on, but rather universal knowledge of spirit as it expresses itself in human history and the state. ${ }^{7}$ For Kierkegaard, self-knowledge cannot be only a third-personal matter, and we might see the portrayal of "A" in Either/Or as a critique of the attempt to take a disinterested, purely third-personal stance towards oneself. ${ }^{8}$ Haufniensis adds: "It is about time to seek to understand it [self-knowledge] in the Greek way, and then again as the Greeks would have understood it if they had possessed Christian presuppositions" (ibid.). The chief such presupposition appears to be sin, the topic which

\footnotetext{
${ }^{6}$ Edward F. Mooney, Selves in Discord and Resolve (New York: Routledge, 1996): 17-19, talks here of willingness rather than wilfulness.

${ }^{7}$ See the editorial note at CA 240.

${ }^{8}$ Cf. Daniel Watts, "Kierkegaard and the search for self-knowledge", European Journal of Philosophy, vol. 21-4 (2013): 530.
} 
frames Kierkegaard's discussion of anxiety. We'll shortly see in more detail the importance of $\sin$ - and its forgiveness - for Kierkegaard's view of self-knowledge.

All this takes us beyond the "ethical" stage to the "religious". In this territory, Kierkegaard puts a greater emphasis on our ultimate dependence upon the mercy of God, insisting that full self-knowledge is not possible. In Christian Discourses (1848), he asks:

\begin{abstract}
Alas, who does know himself? Is it not exactly this to which the earnest and honest self-examination finally leads as its last and truest, this humble confession: "Who knows his errors? From my hidden faults cleanse thou me" (Psalms 19: 12). And when a person examines his relation to Christ, who then is the human being who completely knows his faithlessness, who the human being who would dare to think that in his very self-examination there could not be faithlessness? Therefore you do not find rest this way. So, then, rest; then seek rest for your soul in the blessed comfort that, even if we are faithless, he still is faithful. (CD 287-8/SKS10 308)
\end{abstract}

Elsewhere, however, our "absolute need of God" is presented as a pre-requisite for selfknowledge (or whatever self-knowledge we may have (JP1: 53/Pap. V B 196)). We might relate this emphasis on God-dependence to the famous formula of The Sickness Unto Death (1848), Kierkegaard's major discussion of despair: "The formula that describes the condition of the self when despair is completely rooted out is this: in relating itself to itself and in willing to be itself, the self rests transparently in the power that established it" (SUD 14/SKS11 130, my emphasis). This "resting transparently" is a manifestation of selfknowledge insofar as the self knows what it owes to God, but experiences this not as guilt 
and debt but gratitude for the forgiveness of sins. ${ }^{9}$ Here we start to see the importance of a second-person God-relationship.

Sickness is indeed a text that highlights the difficulty of self-knowledge. The varieties of despair that the author Anti-Climacus portrays are often forms of self-deception in which we wilfully resist the self-transparency Judge William emphasized. Anti-Climacus makes the striking claim that despair is a universal human phenomenon (SUD 22-8/SKS11 138-44). He anticipates that this claim is likely to seem overblown, and suggests that the reason for this is our tendency to overlook that "not being conscious of being in despair, is precisely a form of despair" (SUD 23/SKS11 139). Just as the physician knows that there can be purely imaginary forms of health as well as of sickness, so the "physician of the soul" recognises this is also true of spiritual ill-health. In other words, many of us are in despair without realising it. It is thus precisely a failure of self-knowledge that can hide from me what I most need to grasp.

Sickness also highlights the important link between self-knowledge and knowledge in the abstract. Sometimes, Kierkegaard seems to hold that knowledge per se is only of instrumental value; what really matters is what Climacus, in the Postscript, calls "essential" (that is, ethical and religious) knowledge: "essential" in its value for the task of living. ${ }^{10}$ It is also in this mode - its connection with living ethically and religiously - that self-knowledge is considered indispensable in passages such as that slightly later in Sickness, where knowing is presented in its "fantastic" mode. Some background is necessary here. Anti-Climacus defines the fantastic [Det Phantastiske] as follows:

\footnotetext{
${ }^{9}$ Sickness describes the forgiveness of sins as the crucial difference between Christianity and paganism (SUD 117/SKS11 228).

${ }^{10}$ In this sense, for Kierkegaard, ethical and religious knowledge has a particular claim to be called self-knowledge (cf. Watts, "Self-Knowledge", 538).
} 
The fantastic is generally that which leads a person out into the infinite in such a way that it only leads him away from himself and thereby prevents him from coming back to himself (SUD 31/SKS11 147).

Anti-Climacus then briefly illustrates this through three such forms of the fantastic - feeling; knowing; and willing - through each of which the self becomes weakened or "volatilized" [forflygtiges] and thus "lost". Fantastic feeling replaces a genuine concern for a concrete other with "a kind of abstract sentimentality that inhumanly belongs to no human being" (ibid.). Fantastic willing fails to ally its lofty ambitions with the small part of its grand task that can be accomplished "this very day, this very hour, this very moment" (SUD 32/SKS11 148). What then of fantastic knowing? Here Anti-Climacus claims:

The law for the development of the self with respect to knowing, insofar as it is the case that the self becomes itself, is that the increase of knowledge corresponds to the increase of self-knowledge, that the more the self knows, the more it knows itself. If this does not happen, the more knowledge increases, the more it becomes a kind of inhuman knowledge, in the obtaining of which a person's self is squandered, much the way men were squandered on building pyramids (SUD 31/SKS11 147).

In other words, Anti-Climacus is warning against the valorisation of knowledge abstracted from the concrete concerns of living that Kierkegaard often associates with speculative philosophy. Down that route lies a kind of comical self-forgetfulness to which Kierkegaard seems to think the intellectual is particularly prone. Behind his various satires about losing oneself is a familiar question. What shall it profit a man, he effectively asks, if he shall gain the whole world - of knowledge - and yet lose his own soul? ${ }^{11}$ Here as elsewhere,

${ }^{11}$ Cf. Mark 8: 36. I discuss the philosophical purpose of some of the Postscript's satire in Lippitt, Humour and Irony, especially chapter 2. 
Kierkegaard privileges "essential" knowledge. A major concern in Sickness is the loss of the self in abstraction which Anti-Climacus considers to be a variety of despair (SUD 32/SKS11 148). Yet such a loss of the self - or failure to rise to the task of becoming a self - is presented there as entirely normal:

a self is the last thing the world cares about and the most dangerous thing of all for a person to show signs of having. The greatest hazard of all, losing the self, can occur very quietly in the world, as if it were nothing at all. No other loss can occur so quietly; any other loss - an arm, a leg, five dollars, a wife, etc. - is sure to be noticed (SUD 323/SKS11 148).

Passages such as this have been used in support of reading Kierkegaard as a protoexistentialist, concerned about the inauthenticity of das Man (Kierkegaard's roughly equivalent term for which is the "public"12). And yet there is a specifically Christian dimension to this, as we shall shortly see.

Anti-Climacus briefly returns to the question of self-knowledge a little later, in the guise of the importance of having (in an echo of the Judge) "clarity about oneself" (SUD 47/SKS11 162). He defers to later discussion an important question, namely whether it is possible simultaneously to have such self-clarity and yet still be in despair. In doing so, he also defers discussion of the possibility that such clarity of self-knowledge might "simply wrench a person out of despair, make him so afraid of himself that he would stop being in despair" (ibid.). In other words, could self-knowledge be a cure for despair? Frustratingly, this refers to a section $\mathrm{D}$, contemplated but never written, which was excluded from the final version of the manuscript. ${ }^{13}$ But we can get some idea of what Kierkegaard's answer to this question

\footnotetext{
${ }^{12}$ See especially TA 90-6/SKS8 86-91.

${ }^{13}$ See the Supplement to SUD $177 \mathrm{n} 53$.
} 
would likely have been in two ways. First, a little later, echoing Kierkegaard's view in Christian Discourses, Anti-Climacus hints that a fully realised ideal of self-knowledge is not possible for us. Rather, we are typically dimly aware of being in despair in much the same way as is the person with a physical illness who "does not want to acknowledge forthrightly the real nature of the illness" (SUD 48/SKS11 163). Second, he presents the opposite of despair as being not self-knowledge but faith, in line with the argument of the second part of the book, that despair is sin, for which faith is the only cure.

\section{5) Self-knowledge "before God" - and action}

These themes are continued in Judge for Yourself! (1851), where Kierkegaard offers a more precise specification of what Christian self-knowledge amounts to. In the first section, Kierkegaard defines "becoming sober" thus:

to come to oneself in self-knowledge and before God as nothing before him, yet infinitely, unconditionally engaged (JY 104/SKS16 160).

Christianity and the "purely human point of view" can agree that self-ignorance and selfmisunderstanding are like forms of intoxication (JY 104/SKS16 161). But they disagree on what it means "to come to oneself in self-knowledge" (JY 105/SKS16 161). Kierkegaard compares the "objective knowing" at which speculative philosophy aims to spiritual dizziness. As in the Postscript, objective knowing is presented as occasioning a selfforgetfulness that is the very opposite of the self-knowledge that sobriety requires.

For Kierkegaard, only the self-knowledge that leads to knowing oneself "before God" is selfknowledge of the right sort. Extending the earlier references to self-transparency, the claim is now explicitly that the transparency of sobriety is only possible before God. In the same way as the expert lash of the royal coachman brings his horse up short, forcing a realisation of 
who is boss, so God, without whom I am nothing, brings home to me "the unconditioned" [det Ubetingede] - and this realisation is what makes me sober (JY 107-9/SKS16 163-5). In this condition, one comes to oneself "as nothing", and realises one's absolute dependence upon God. ${ }^{14}$

Is this paralysing? No, apparently, because although one becomes "as nothing", one does so in a way that is "infinitely, unconditionally engaged" (JY 106/SKS16 160) such that "all one's understanding becomes action" (JY 115/SKS16 170). As Kierkegaard is famous for saying, life must be lived forwards. To do what one understands is an effort, and so we tend to focus all our attention on understanding or knowing, pretending that this is where the difficulty lies. This is precisely the ethico-religious evasion about which Kierkegaard so often warns. But whereas mere knowing can leave one's life untouched, ${ }^{15}$ "my action changes my life" (JY 116/SKS16 171) and "the truly simple exposition of Christianity is - to do it" (ibid.): and "immediately" (JY 120/SKS16 175). This is true sobriety.

An associated journal entry from 1851 gives one of Kierkegaard's clearest statements on how he understands the ideal of self-knowledge. The topic is "What is Required in Order to Look at Oneself with True Blessing in the Mirror of the Word" (JP4: 3902/Pap. X4 A 412). ${ }^{16}$ Here he suggests that a certain degree of self-knowledge is necessary in order for the self-

\footnotetext{
${ }^{14}$ In their introduction to their collection of Kierkegaard's writings from the last two years of his life, the Hongs suggest that ultimately for Kierkegaard "Self-knowledge comes through imitating [Christ], and spiritual progress becomes retrogression in the light of the ideal requirement" (M xii). This is in line with the idea expressed as early as the sermon at the end of Either/Or, that in relation to God we are always "in the wrong". But it means, controversially, that there is a kind of self-knowledge that is only available to the Christian.

${ }^{15}$ I assume the warning here is about "fantastic" knowing, as discussed above.

${ }^{16}$ For an insightful study of Kierkegaard's use of mirror imagery, see Patrick Stokes Kierkegaard's Mirrors (Basingstoke: Palgrave, 2010).
} 
recognition here discussed to be possible at all. But in what follows, the above claims are crystallised in a particularly succinct way:

Paganism required: Know yourself. Christianity declares: No, that is provisional know yourself - and then look at yourself in the Mirror of the Word in order to know yourself properly. No true self-knowledge without God-knowledge or [without standing] before God. To stand before the Mirror means to stand before God. (ibid.)

Only "before God" can I truly see myself - the mirror provides a continual "Thou art the man" (FSE 35-40/SKS13 62-6) - and any self-knowledge that falls short of this revelation is a "fraud" (JP4: 3902/Pap. X4 A 412). ${ }^{17}$

To clarify: the primary meaning of "the Word" here means scripture (not God qua logos), ${ }^{18}$ while "God-knowledge" means not "objective" third-person knowledge of the divine, but an essentially two-way second-person "God-relationship" in which God loves his creatures, who in turn stand "before God" in faith. The focus is more on "knowing God" in a relational sense than on knowing about God.

We should also note how Kierkegaard cashes out the need for this ruthless self-examination. Although he concludes the journal entry by emphasising the importance of "an implacable hatred for the self that the mirror shows as being that to which one should die" (ibid.), we

\footnotetext{
${ }^{17}$ However, Kierkegaard thinks the recognition one can find in the Mirror of the Word is already there in embryonic form in Socrates. In his later writings on the Greek thinker, Kierkegaard takes Socrates to draw a key distinction between human and divine wisdom, and "to ground claims of human wisdom in an individual's ability to remain aware of that distinction" (Muench, "Kierkegaard's Socratic", 20). Thus he claims: "Socrates' ignorance was a kind of fear and worship of God, ... the Greek version of the Jewish saying: The fear of the Lord is the beginning of wisdom" (SUD 99/SKS11 211).

${ }^{18}$ See especially FSE 25/SKS13 53-4. Kierkegaard's discourse on this topic (FSE 751/SKS13 39-76) is a reflection on James 1: 22-27, which is about putting one's faith into action.
} 
should not miss the preceding passage, in which two kinds of error are stressed. In wanting only the truth, one should "neither vainly wish to be flattered nor self-tormentingly want to be made a pure devil". This second error is just as important as the first: for all his focus on sin, Kierkegaard is at least as concerned with the forgiveness of sins and its link to selfforgiveness, ${ }^{19}$ a topic with which he wrestled, on a deeply personal level, for most of his life. That the God before whom we stand is a God of love who forgives our sins is for Kierkegaard the ultimate good news. There is a dialectic at work in self-knowledge analogous to that in self-love, Kierkegaard being concerned to tease out the difference between proper and improper forms of the latter. Just as I must come in a certain sense to hate myself in order to be able to love the version of myself I should love, so I need to recognise the limits of what I can naturally know about myself in order that true self-knowledge may (at least to an extent) be possible: by looking at myself in the Mirror of the Word.

This allows us finally to return to the question of whether we should understand selfknowledge in first- or third-personal terms - and how this also involves a second-person element. We are now better placed to see how Kierkegaard is trying to combine these factors. ${ }^{20}$ While rejecting the third person ("German") view, it is misleading to see him as committed to the single, isolated subject being the sole defining locus of selfhood. There are plenty of instances where Kierkegaard sounds like he is signed up to this picture (not least in the slogan "truth is subjectivity"), but it is now increasingly recognised that he intends for this to serve as a corrective to a misapplied objectivity of the kind associated with speculative philosophy: a rescuing of the particular from the universal; of individual being from thought (see CA 78n/SKS4 381). The subjective thinker's task is to understand himself - including

\footnotetext{
${ }^{19}$ See John Lippitt, Kierkegaard and the Problem of Self-love (Cambridge: Cambridge University Press, 2013): chapter 8.

${ }^{20}$ See also Watts, "Self-knowledge".
} 
(though not limited to) the sheer givenness of such "universal" aspects as his creatureliness in his concrete, particular existence. "No true self-knowledge without God-knowledge": the journal passage is one of many in which Kierkegaard seeks to combine first, second and third personal aspects as outlined above. This is, then, also how we should understand his remark that self-knowledge should be understood "in the Greek way, and then again as the Greeks would have understood it if they had possessed Christian presuppositions" (CA 79/SKS4 382). As we have seen, the concept the Greeks lacked is sin. I need to understand sin as an objective property in which all humanity is implicated, ${ }^{21}$ but to relate to this on a first-person, subjective level as something that applies to me. Standing "before God" (second-person) is what brings this home. The focus on the phenomenology of feelings and moods that Kierkegaard undertakes in his works on anxiety and despair highlight this subjective dimension (and there is a lengthy discussion of "subjective anxiety"), but these are meant to be universal claims about the human condition. ${ }^{22}$ One of the uses of anxiety, it emerges in the final chapter of The Concept of Anxiety, is the insight it gives us into our own guilt. Haufniensis' claim that "if a man is guilty, he is infinitely guilty" (CA 161/SKS4 460) means that no guilty person can make himself once again innocent. What this highlights is the need for an external forgiver of sins: the ability to forgive sins is a "chasmal qualitative abyss" between God and man (SUD 122/SKS11 233). I need to know - third-personally - that sins can be forgiven, but also to grasp - first-personally - that this applies to me. As Kierkegaard seems to have experienced first-hand, this move is far from automatic, but - he thinks - it is a

\footnotetext{
${ }^{21}$ See Gregory R. Beabout Freedom and its Misuses: Kierkegaard on Anxiety and Despair (Milwaukee: Marquette University Press, 1996): 53-4.

${ }^{22}$ Early on, Haufniensis distinguishes between "dogmatics" and "psychology" and claims to be engaged in the latter. But Beabout plausibly suggests that what he means by "psychology" is closer to philosophical anthropology: he is concerned with the "study, description and explanation" of what is essential to being human (ibid., 36).
} 
gift of grace. ${ }^{23}$ Ultimately, then, from Kierkegaard's Christian point of view, a key part of self-knowledge is to experience myself as a sinner whose sins have been forgiven. What Climacus would call "old fashioned orthodoxy" is for Kierkegaard both the deepest form of self-knowledge, and the most valuable gift of grace.

${ }^{23}$ Indeed, he claims that only God can grant not only forgiveness, but the condition that enables the believer to believe in it (WL 379-80/SKS9 372-3). 


\section{Bibliography}

\section{Primary Sources}

In quoting from Kierkegaard's works, I refer to page numbers of the following editions:

SKS Søren Kierkegaards Skrifter. Vols 1-28 and K1-28, ed. Niels Jørgen Cappelørn et al. (Copenhagen: Gad, 1997-).

English translations used are from Kierkegaard's Writings, published by Princeton University Press and translated (unless otherwise stated) by Howard V. and Edna H. Hong. Texts from which I explicitly quote, and the sigla used, are as follows:

CA The Concept of Anxiety. Trans. Reidar Thomte (1980)

CD Christian Discourses (1997)

CI The Concept of Irony (1989)

CUP Concluding Unscientific Postscript (1992)

EO Either/Or, 2 volumes (1987)

FT/R Fear and Trembling and Repetition (1983)

JY Judge for Yourself! (1987)

LD Letters and Documents. Trans. Henrik Rosenmeier (1978)

M The Moment and Late Writings (1998)

PF Philosophical Fragments (1985)

SUD The Sickness Unto Death (1980) 
TA Two Ages (1978)

WL Works of Love (1995)

Citations of Kierkegaard's journals and notebooks are from both the ongoing - but as yet incomplete - translation (giving entry by Kierkegaard's own numbering system, used by both SKS and KJN) and also an older edition (giving both volume and entry number (e.g. JP3: 2425)), viz:

KJN Kierkegaard's Journals and Notebooks, ed. Niels Jørgen Cappelørn et al (Princeton: Princeton University Press, 2007-)

JP Søren Kierkegaard's Journals and Papers, 7 vols, ed. and trans. Howard V. and Edna H. Hong (Bloomington: Indiana University Press, 1967-78).

\section{Secondary Sources}

Beabout, Gregory R. Freedom and its Misuses: Kierkegaard on Anxiety and Despair (Milwaukee: Marquette University Press, 1996).

Hong, Howard V. and Edna H. Hong, "Historical Introduction", in The Moment and Late Writings, ix-xxxi.

Lippitt, John Humour and Irony in Kierkegaard's Thought (Basingstoke: Palgrave, 2000). Lippitt, John Kierkegaard and the Problem of Self-love (Cambridge: Cambridge University Press, 2013).

Mooney, Edward F. Selves in Discord and Resolve (New York: Routledge, 1996).

Muench, Paul “Kierkegaard's Socratic point of view”, in Kierkegaard Research: Sources, Reception and Resources, Vol. 2, Kierkegaard and the Greek World, Tome I: Socrates and Plato, eds. Jon Stewart and Katalin Nun (London: Ashgate, 2010), 3-25. 
Stokes, Patrick Kierkegaard's Mirrors (Basingstoke: Palgrave, 2010).

Thomte, Reidar, "Historical Introduction", in The Concept of Anxiety, vii-xviii.

Watts, Daniel "Kierkegaard and the search for self-knowledge", European Journal of Philosophy, vol. 21-4 (2013): 525-549. 